\title{
Modeling of the heating transfer in the karst aquifers for Val d'Orléans city (France)
}

\author{
Ali Salim Joodi \\ Department of Environmental Eng., Collage of Engineering, Al-Mustansiriya Univ, Baghdad (Iraq) \\ Rec. 17 Nov, 2011 Accpt. 12 Dec, 2011
}

\begin{abstract}
:
In karst aquifers, temperature distribution play an additional important role since they carry information about internal aquifer structures. The aim of the present work is to develop a two dimensional heat transfer model in a karst aquifer. Navier Stokes equation is used to simulate the groundwater velocity in the conduit system where the porosity tends to one, and means water velocity was taken into account in the fractured rock. Heat transport equation was applied to simulate the temperature distribution in a karst aquifer, and $\mathrm{k}-\varepsilon$ turbulent model is used to simulate the turbulent viscosity. The model was applied to the karst system of Val d'Orléans. Temperatures are measured in thirteen wells with different depth in 29 Jun 2011. Results have shown that the model was not sensitive to the variation of water density, but it is sensitive to the variation of specific heat and density of the rock especially in the fractured system. Also, the model was varied sharply with the velocity of water in sinkhole points, and any variation in the depth of saturated zone. The comparison between measured and calculated temperatures in wells is very good.
\end{abstract}

Key word: Karst aquifers, Heat transport, Conduit and diffuse flow systems, Numerical model and Val d'Orléans

\section{Introduction:}

Karst forms when groundwater dissolves pockets of limestone, dolomite, or gypsum in bedrock. This dissolution process increases the bulk permeability of the massif, developing a conduit network of high hydraulic conductivity, with short water residence time, and preserving micro fractured blocks with long water-residence time (Dogwiler et al., 2007). Thus, karstification provokes flow heterogeneity, increasing the permeability contrast between conduit flow and diffuse flow systems. Karst system is mainly characterized by four elements. The first is sinkholes which recharge the karst system. The second is the underground drainages or conduits which are largely influenced by sinkholes and consequently the water flow in these regions is high. The third is fractured system (diffused system) which is weakly influenced by sinkhole and consequently the water flow in these regions is slow. The last is spring point in which the water is emerged at the surface. In this context, karst systems are highly vulnerable compared to other groundwater systems, since potential contaminants can easily reach the groundwater (Genthon et al., 2005; O'Driscoll and DeWalle, 2006; Dogwiler et al., 2007).

The use of heat as a groundwater tracer, in contrast to the use of chemical tracers, is attractive because of the ease of measuring temperature with high precision (errors as low as \pm 0.03 _C). Groundwater temperatures are influenced by the temperature of recharge, mixing of different waters resulting from groundwater flow. (Andrieux, 1978; Crowther and Pitty, 1982; Roy and Benderitter, 1986; Lastennet, 1994; Martin and Dean, 1999; Birk et al., 2004). have used water temperature jointly with other natural hydro dynamical and hydro chemical responses, as additional information to characterize the different flow types and the structural

organization of drainage patterns in karst aquifers. Groundwater applications have been developed to model quick-flow in karst conduits, diffuse flow in fractured and, and the

\footnotetext{
* Corresponding author:

Dr. Ali Salim Joodi

$\bowtie$ ali.joodi@orleans-univ.fr
} 
interaction of these two flow regimes. Fluid flow and solute/ heat-transfer numerical models that include both of these flow regimes include (Benderitter et al., 1993; Liedl and Sauter, 2000; Birk, 2000; Andre and Rajaram, 2005; Birk et al., 2004). With these distributed-parameter models, velocities are estimated from the flow simulation and then are used in the transport simulation. Additional insight into general heat-transfer theory for pipe and channel flow is described by (Gnielinski, 1976; Aravinth, 2000; Beek et al., 1999; Benim et al., 2004). As the conduits are highly influenced by the contamination of rivers (as the water of sinkholes), any information on conduit locations usually is unavailable. For cases where wells or springs have a temperature response that is influenced by conduit flow, the conduit network is globally defined. This paper presents a twodimensional numerical water flow /heat transport model that is explored as an alternative that might be useful to locate the conduit networks in the karst system of the Val d'Orléans. This model simulates the temperature response to recharge in wells and assumes that wells receive at least some of its water from a nearby conduit. The water flow will be simulated in conduit system by Navier Stokes equation, but the model does not simulate the water flow in the fractured system (in which the permeability is less than that in the conduit system). The water velocity in the fractured system will be carried out as mean velocity. The results of the model will be verified with temperatures observed in the wells. The viscosity gradient will be calculated by using K epsilon turbulent model.

\section{Characteristics of the experimental field} area:

The karst aquifer of the Val d'Orléans is the largest in France in terms of flow rate (10 $\mathrm{m}^{3} / \mathrm{s}$ ) and provides the mean water resource of the Orléans city (Albéric and Lepiller, 1998). The Val d'Orléans is considered as a vast depression of the major bed of the Loire river, $37 \mathrm{~km}$ long and from 4 to $7 \mathrm{~km}$ wide (Fig. 1). The karst aquifer is hosted within an Oligocene carbonate lacustrine deposit occurring in the center of the Paris basin and called the limestone of Beauce (Guillocheau et al., 2000). This latter formation display variable repartition with a significant primary porosity except for micritic facies, this porosity is increased by karstification leading to a relative high permeability (5E-10 to $2 \mathrm{E}-9$ m2) at hectometric scale (Martin and Noyer, 2003). The latter is overlapped by the quaternary alluvia of the Loire river.

The Loire river feeds more than $85 \%$ of the water hosted in the carbonated karstic aquifer. The estimated inflow of the Loire river in the sinkhole infiltration area of Jargeau varies from 15 to $20 \mathrm{~m}^{3} / \mathrm{s}$ and it can reach $100 \mathrm{~m}^{3} / \mathrm{s}$ during floods (Zunino, 1979; Chéry, 1983; Lepiller and Mondain, 1986). Karst networks are well known in the left bank of the Loire river. The water runs from Jargeau through the karst conduits networks towards the direction of the springs of the Loiret river, (Zunino, 1979; Chéry, 1983; Lepiller and Mondain, 1986), as shown in figure (1). The springs of Loiret river are called the Bouillon and the Abîme, they are considered as the main emergences of the water lost close to Jargeau in the Loire river (from 0.3 to $5 \mathrm{~m}^{3} / \mathrm{s}$ ). The mean aquifer outflow is an underground emergence in the Loire river located around the confluence of Loire - Loiret. Previous studies showed the relation between these springs and the sinkholes points at Jargeau within the Loire river using dye tracer tests (Zunino, 1979; Chéry, 1983; Albéric and Lepiller, 1998; Lepiller, 2001; Albéric, 2008).

The main karstic conduits were located according to the depressions of the piezometric surface and to the different connections identified by the tracer tests presented in figure (1).

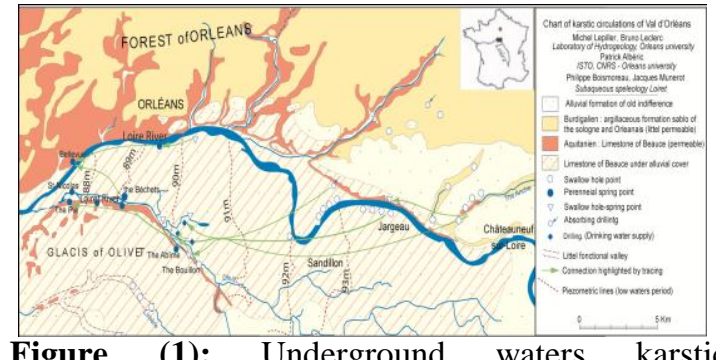

Figure (1): Underground waters karstic circulations of the Val d'Orléans city (Albéric and Lepiller, 1998). 


\section{Governing equations:}

Numerical simulations of fluid flow and heat transport in a karst aquifer were used to investigate the temperature distribution in the karst and by consequence to determine the karstification degree of the karst aquifer. In the present work, Navier Stokes equation is applied to simulate the water velocity in conduit system, as a result to the grand porosity in this system. A uniform velocity is taken in the fractured rock system where the porosity is highly less than that in conduit system. To determine the temperature distribution in the karst, heat transport equation is used. Due o the variation of the temperature in the karst system, the viscosity will be changed, and to calculate this variation $\mathrm{K}$ epsilon turbulent model is used.

Navier Stokes equation for two dimension is:

$\rho_{\mathrm{w}} \frac{\partial \mathrm{q}_{\mathrm{w}}}{\partial \mathrm{t}}+\mathrm{q}_{\mathrm{w}} \nabla \rho_{\mathrm{w}} \mathrm{q}_{\mathrm{w}}=-\nabla \mathrm{p}+\nabla^{2} \mathrm{q}_{\mathrm{w}} \mu+\rho_{\mathrm{w}} \mathrm{g}$

Heat transport equation in the karst for two dimension is:

$\frac{\partial}{\partial \mathrm{t}}\left\{(1-\phi) \rho_{\mathrm{r}} \mathrm{C}_{\mathrm{r}} \mathrm{T}+\phi \rho_{\mathrm{w}} \mathrm{C}_{\mathrm{w}} \mathrm{T}\right\}+\phi \mathrm{q}_{\mathrm{w}} \rho_{\mathrm{w}} \mathrm{C}_{\mathrm{w}} \nabla \mathrm{T}=\lambda \nabla^{2} \mathrm{~T}$

$\mathrm{K}$ epsilon turbulent model for two dimension is:

$\rho_{\mathrm{w}} \frac{\partial \mathrm{k}}{\partial \mathrm{t}}+\mathrm{q}_{\mathrm{w}} \nabla \rho_{\mathrm{w}} \mathrm{k}=\nabla^{2}\left(\frac{\mu}{\sigma_{\mathrm{k}}} \mathrm{k}\right)+\mathrm{G}-\rho_{\mathrm{w}} \mathrm{E}$

$\rho_{\mathrm{w}} \frac{\partial \varepsilon}{\partial \mathrm{t}}+\mathrm{q}_{\mathrm{w}} \nabla \rho_{\mathrm{w}} \varepsilon=\nabla^{2}\left(\frac{\mu}{\sigma_{\varepsilon}} \varepsilon\right)+\mathrm{C}_{1} \frac{\varepsilon}{\mathrm{k}} \mathrm{G}-\mathrm{C}_{2} \rho_{\mathrm{w}} \frac{\varepsilon^{2}}{\mathrm{k}}$

To calculate the turbulent viscosity, the following equation is used:

$\mu_{\mathrm{t}}=\mathrm{C}_{\mu} \rho_{\mathrm{w}} \frac{\mathrm{k}^{2}}{\varepsilon}$

Where:

$\rho_{\mathrm{w}}$ is the water density, qw is water velocity vector, $\mathrm{t}$ is the time, $\mathrm{p}$ is the water pressure, $\mathrm{g}$ is the acceleration gravity, $\phi_{i s}$ the porosity of the karst system, $\rho_{\mathrm{r}}$ is the rock density, $\mathrm{C}_{\mathrm{r}}$ is the specific heat of the rock, $\mathrm{C}_{\mathrm{w}}$ is the specific heat of the water, $\mathrm{T}$ is the water temperature, $\lambda$ is the heat conductivity, $\mathrm{k}$ is the turbulence kinetic energy, $\varepsilon$ is the dissipation rate of turbulent kinetic energy, $\mathrm{G}$ is the production of turbulence kinetic energy, $\sigma_{k}, \sigma_{\varepsilon}, C_{1}, C_{2}$, $\mathrm{C}_{\mu}$ are constants. Les valeurs des constantes sont (Leschziner et Rodi, 1983).

$C_{\mu}=0.09, \mathrm{C} 1=1.44, \mathrm{C} 2=1.92, \sigma_{\varepsilon}=1.3, \sigma_{\mathrm{k}}=1$

In the present work, the variation in the density of water and rock can be calculated from equations (6) and (7), respectively. The variation in the specific heat of water and rock can be calculated from equation (8) and (9), respectively (Somerton, 1992; Douglas and Jacob, 2004).

$$
\begin{aligned}
& \rho_{w}(T)=1043.196-42.966623 \exp (0.006895 \mathrm{~T}) \\
& \rho_{\mathrm{r}}(\mathrm{T})=\frac{2650}{1+(\mathrm{T}-2 \mathrm{O}) \times 0.5 \times 10^{-4}} \\
& \mathrm{C}_{\mathrm{w}}(\mathrm{T})=\frac{1}{0.0002374+8.06817 \times 10^{-8} \mathrm{~T}-8.03671 \times 10^{-10} \mathrm{~T}^{2}} \\
& C_{r}(T)=1234.257-454.546 \exp (-0.0039733 \mathrm{~T})
\end{aligned}
$$

Heat transport in the karst system of the Val d'Orléans:

Karst system of the Val d'Orléans has many sinkhole points which are located on the Loire river at the city of Jargeau, and it has many spring points as shown in figure (1). In this work, the temperature is monitored at thirteen wells and one spring point located in the karst system of the Val d'Orléans. In general, water in the conduit includes sinking river water and diffuse flow (from fractured system) entering the conduit along its length. In addition to water from the conduit, a well or spring also might receive local diffuse flow that has not interacted with the conduit. For example, a well that is south of the conduit may induce flow from the conduit and also from diffuse flow within the well's zone of influence on the north, south, and east sides of the well (Fig. 2) and consequently it can be observed a variation in the water temperature of the well. But in the most cases, it can be observed many wells in which the temperature is constant. This can be attributed to the location of the well, the variation of the water temperature in the well decrease when the well far away from the conduit and vice ve 


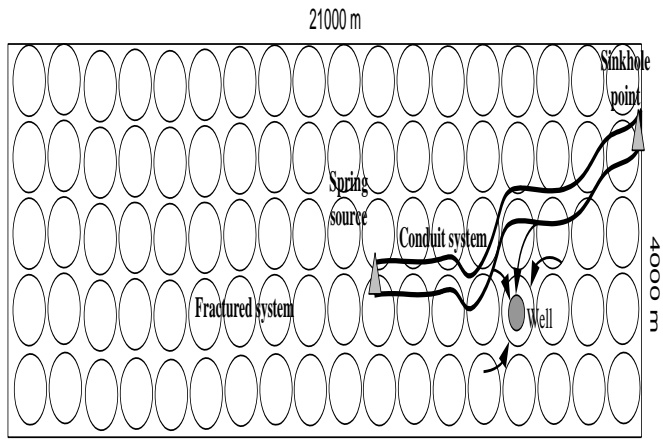

Figure (2): Schematic diagram of a karst system

Depending on the previous description, the temperature is monitored at thirteen wells and one spring point located in the karst system of the Val d'Orléans. Position of wells in the calculational region is illustrated in Fig. (3). The temperature measurements in wells are shown in figures (4,5 and 6). These measurements are provided in 29/06/2011 when the temperature of Loire river and the Bouillon spring were $26.5{ }^{\circ} \mathrm{C}$ and $15.6{ }^{\circ} \mathrm{C}$, respectively. figure (4) shows that the water temperature in wells of Ligne, Piezometre, and Moret is nearly stable but in the well of Moret 2 , the temperature deceases $3{ }^{\circ} \mathrm{C}$ starting from the depth of $12 \mathrm{~m}$. This variation in the temperature can be attributed to the water coming from the conduit system. The variation of groundwater temperature in wells of Boires 1 and Boires 2 is greater than that in the well of Moret 2, as shown in figure (5).

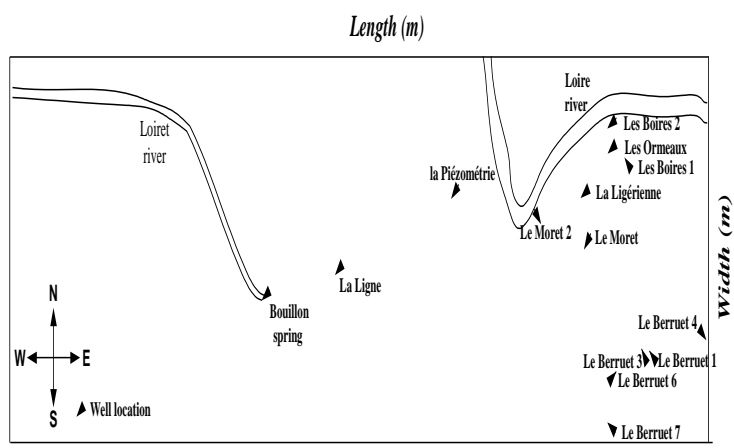

Figure (3): Wells location in the karst system of the Val d'Orléans

In these wells, the variation reaches to $12^{\circ} \mathrm{C}$, this means that these wells are close to the conduit system. But the temperature is stable in wells of Ligerienne and Ormeaux. Figure (6) shows the wells of Berruet 1 and Berruet 3 are affected by the conduit system but less than that in wells of Boires 1 and Boires 2.

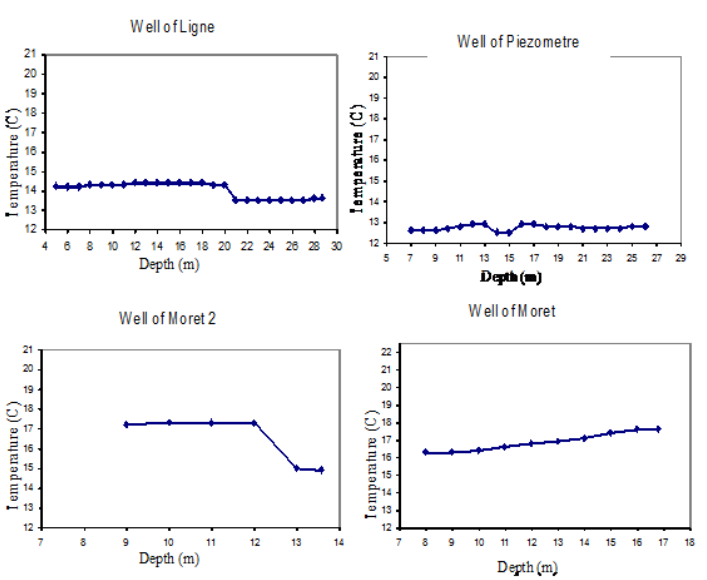

Figure (4): Water temperatures measurements in wells of Ligne, Piezometre, Moret 2, and Moret
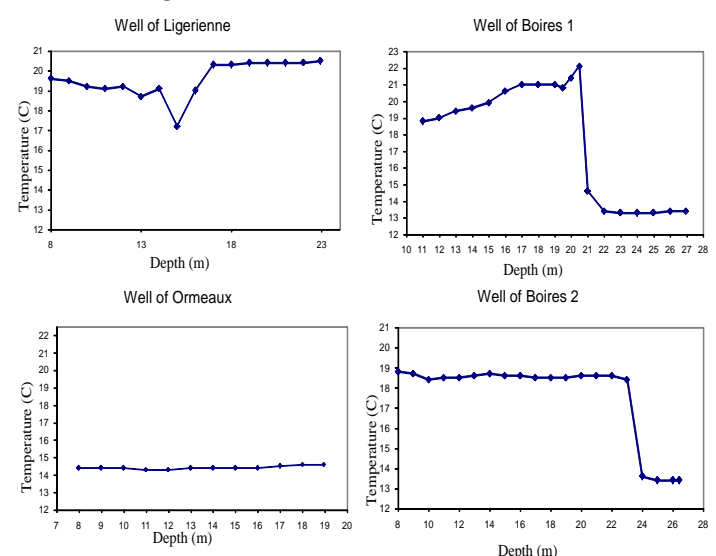

Figure (5): Water temperatures measurements in wells of Ligerienne, Boires 1, Ormeaux, and Boires 2.
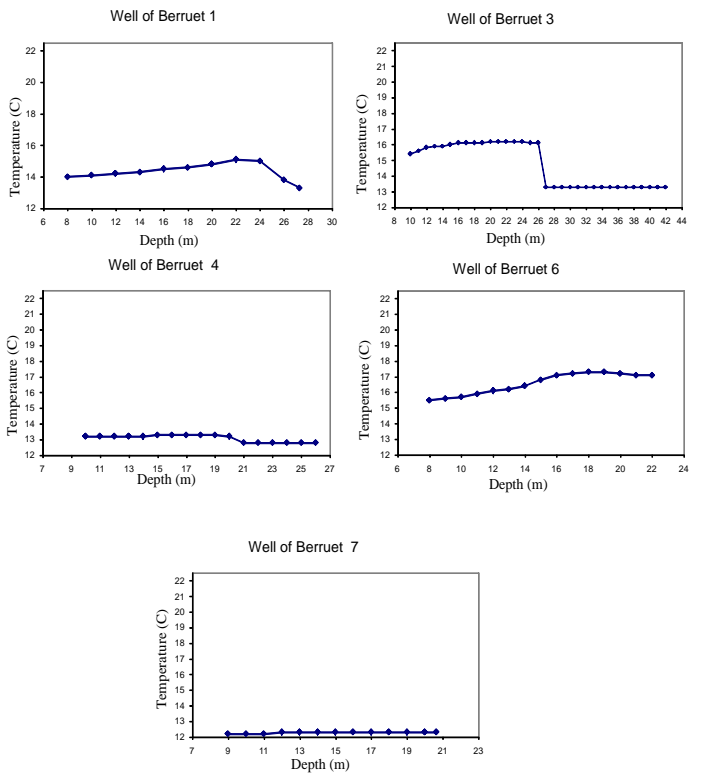

Figure (6): Water temperatures measurements in wells of Berruet 1, Berruet 3, Berruet 4, Berruet 6, and Berruet 7 


\section{Mathematical modeling:}

The study area in the karst aquifer of the Val d'Orléans starts from Jargeau (where the sinkholes on the Loire river are existed) to the last spring point on the Loiret river. The study area is considered as a rectangular area with the length $21000 \mathrm{~m}$ and the width $4000 \mathrm{~m}$. Two dimension numerical model is carried out to simulate the water temperature distribution in the karst system of the Val d'Orléans. The porosity in conduit system and in the fracture rock system is $90 \%$ and $10 \%$ respectively. The pathway of the conduit system suggested in the present research is shown in figure (7). This pathway is suggested according to (Lepiller, 2001; Albéric, 2008).

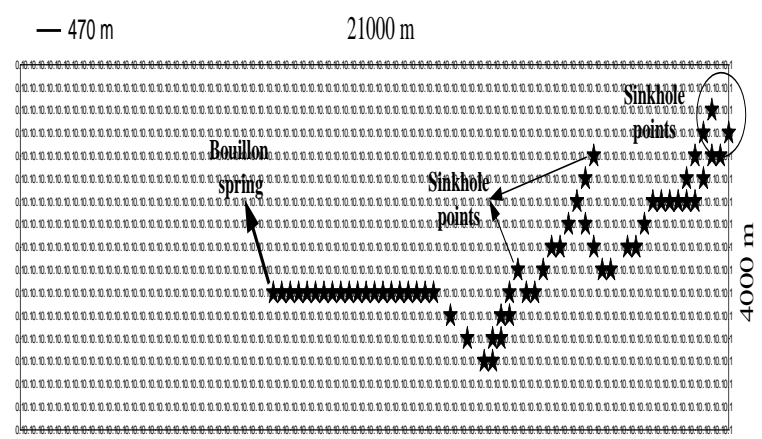

Figure (7): Porosity field and conduit system pathway suggested in the karst system of the Val d'Orléans (Lepiller, 2001; Albéric, 2008).

Initial conditions constitute values of velocity, temperatures, density and specific heat of the water and rock, water viscosity, turbulent kinetic energy and dissipation rate of turbulent kinetic energy. Concerning the velocity, it is carried out the velocity value measured during the summer season. Then the water velocity inlet to the conduit system is 75 $\mathrm{m} / \mathrm{hr}$, this velocity is varied in the conduit system according to Navier Stokes equation, but it is constant in the fractured rock matrix. The velocity inlet to the fractured rock system is a half of previous velocity. Initially the temperature in the study area is that measured in the Bouillon spring on 29 Jun 2011, it was $15.6{ }^{\circ} \mathrm{C}$, expect on the sinkhole points on the Loire river in which the initial water temperature is that measured on Loire river, it was $26.5{ }^{\circ} \mathrm{C}$ on 292011 . The initial values for the density and specific heat of the water and rock are calculated from equations $(6,7,8$, and 9). The initial values of water viscosity, kinetic energy and dissipation rate of turbulent kinetic energy are obtained by the following equations:

$$
\begin{aligned}
& \boldsymbol{\mu}=0.077 \rho \mathbf{U}_{*} \mathbf{h} \\
& \varepsilon=\text { Sgq }_{\mathrm{w}}
\end{aligned}
$$

Where: $\mathrm{h}$ is the mean water depth (depth of saturated zone in the karst aquifer), $\mathrm{S}$ is the piezometric of the water slope, $U_{*}$ is the friction velocity which is equal to $\sqrt{\text { ghS }}$. The piezometric of the water slope is calculated in each region in the study area according to the piezometric map provided by (Zunino, 1979). Equation (5) is used to calculate the initial value of turbulent kinetic energy.

Boundary conditions of the study area are illustrated in fig (8). The finite differences technique is used to solve partial differential equations in the present numerical model. The length and width increments are $5 \mathrm{~m}$. Also, the final time of the model is three months and the time step is $5 \mathrm{~min}$, and the thermal conductivity is $1.3 \mathrm{~J} / \mathrm{sec} . \mathrm{m} .{ }^{\circ} \mathrm{C}$.

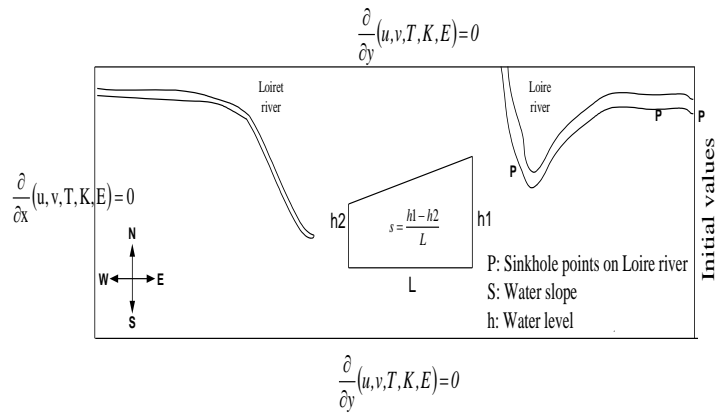

Figure (8): Boundary conditions of the two dimension numerical model

\section{Results and discussions:}

Many parameters influence on the water temperature distribution in a karst aquifer, as the depth of saturated zone, water velocity, viscosity and density effects, porosity, density and specific heat of the rock. Therefore, it was important to study the effect of the variations of these parameters separately to describe the rate and pattern of heat transport and prioritize their influences.

Neglecting the density difference between the temperature of Loire river and groundwater temperature is carried out to study the effect of density on the temperature distribution, and keeping a constant density 
during a time period of study equal to initial groundwater density. A comparison between isotherms with and without density effect is shown in fig (9). It can be clearly observed, all isotherms are not influenced by the change of water density. This due to the small temperature difference between Loire river temperature $\left(26.5{ }^{\circ} \mathrm{C}\right)$ and groundwater temperature $\left(15.6{ }^{\circ} \mathrm{C}\right)$. To investigate the effect of the variation of water slope along the study reach which is coming from the piezometric map, a constant water slope along the study reach is taken into account. From fig (10), it can be observed that the water slope parameter influences on the behavior of temperature distribution. When the water slope is varied, the distribution of temperature levels advances more in transverse direction as that when the water slope is constant.

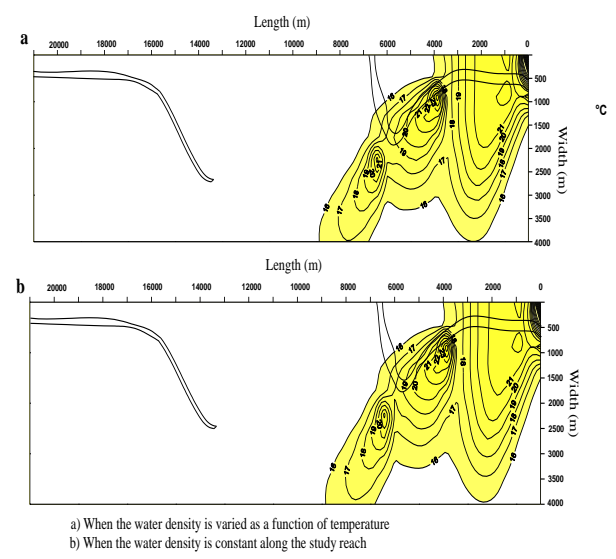

Figure (9): Effect of water density on the behavior of groundwater temperature distribution.

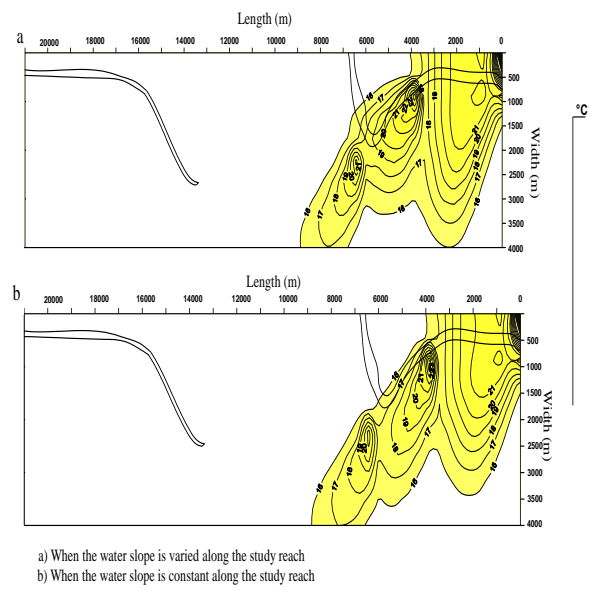

Figure (10): Effect of water slope on the behavior of groundwater temperature distribution.
The water velocity in sinkhole points on Loire river has a great effect on the behavior of temperature distribution along the study reach. As shown in fig (11), all isotherms are advanced longitudinally and transversely with any increase in the water velocity values. This phenomenon can be attributed to the effect of advective term in the heat transport equation, which is responsible for the advance of isotherm along the study reach. Fig (12) shows the effect of water depth in the saturated zone. According to Albéric and Lepiller (1998). the mean depth of saturated zone for the karst system of the Val d'Orléans is $25 \mathrm{~m}$. Any decrease in the depth of saturated zone causes a retardation of the temperature isotherms along the study reach, as shown in fig (12). This can be attributed to the effect of the depth of saturated zone on the friction velocity and water viscosity and by consequence on the temperature distribution. In order to show the effect of the variation of the specific heat and the density of the rock on the behavior of the temperature distribution, equations (7) and (9) are neglected. This means that the specific heat and the density of the rock are constant in the calculations. In the case of the specific heat and the density of the rock are constant, all isotherms are retarded in the transverse direction, but they are advanced in the longitudinal direction, as shown in fig (13). This may be due to the effect of the specific heat and the density of the rock on the domain of fractured system in the karst aquifers only.

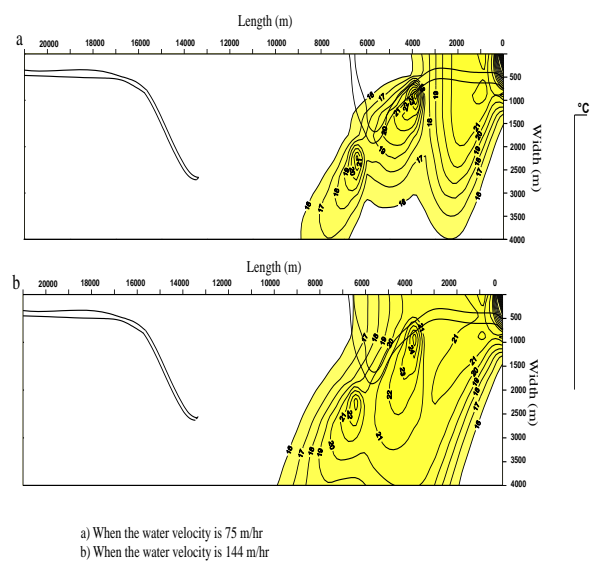

Figure (11): Effect of water velocity on the behavior of groundwater temperature distribution. 


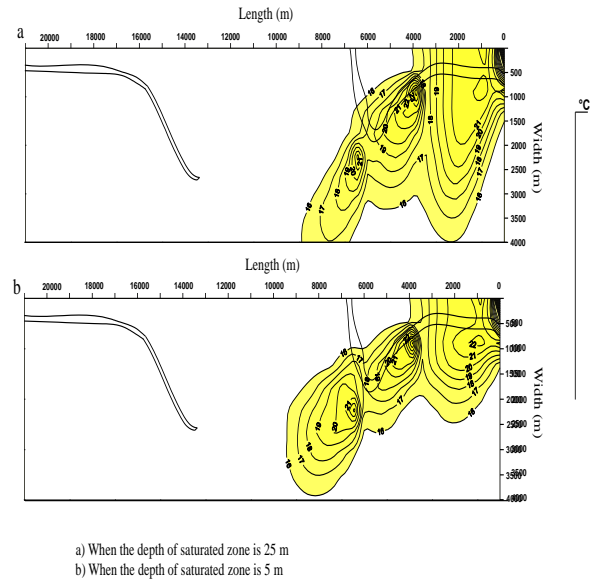

Figure (12): Effect of the depth of saturated zone on the behavior of groundwater temperature distribution.

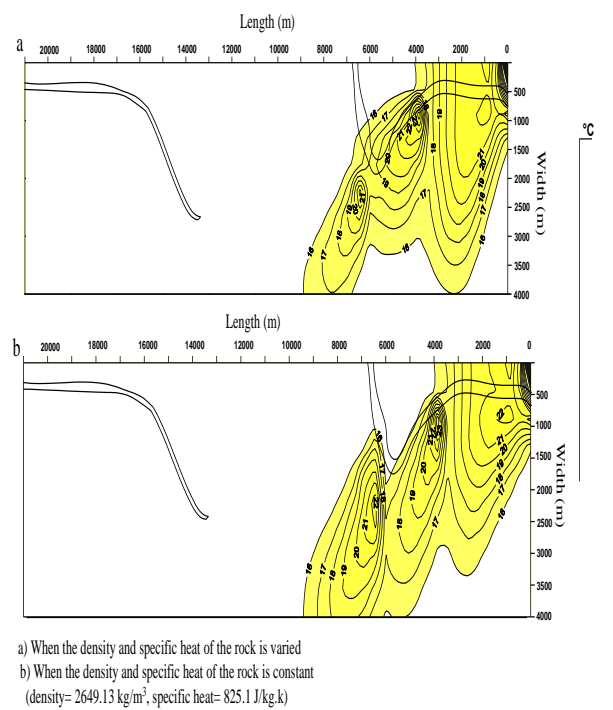

Figure (13): Effect of the density and specific heat of the rock on the behavior of groundwater temperature distribution

In order to verify the accuracy of the present numerical model, a comparison between measured and calculated temperatures in wells is occurred. The best results are obtained when the water velocity in sinkhole points is 80 $\mathrm{m} / \mathrm{hr}$, the porosity is $10 \%$ in the fractured system and $80 \%$ in the conduit system and the depth of saturated zone is $25 \mathrm{~m}$. Table (1) displays this comparison with the percentage error for each well. It can be clearly observed that the results of the model are very good compared with the measured temperature. The percentage error of the model ranges from zero to 17.8 percent.

\begin{tabular}{|l|l|l|l|}
\hline Well & $\begin{array}{l}\text { Measured } \\
\text { temperatur }\end{array}$ & $\begin{array}{l}\text { Calculated } \\
\text { temperatur }\end{array}$ & $\begin{array}{l}\% \\
\text { Erro }\end{array}$ \\
\hline Berruet 1 & 15.1 & 15.7 & 3.9 \\
\hline Berruet 3 & 16.2 & 16 & 1.2 \\
\hline Berruet 4 & 13.3 & 15.1 & 13.5 \\
\hline Berruet 6 & 17.3 & 16 & 7.5 \\
\hline Moret & 17.6 & 17.8 & 1.1 \\
\hline Boires 1 & 22.1 & 20.1 & 9 \\
\hline Ligne & 14.4 & 15.1 & 4.8 \\
\hline & 12.9 & 15.2 & 17.8 \\
\hline Moret 2 & 17.3 & 17.1 & 1.1 \\
\hline Boires 2 & 18.8 & 18.5 & 1.5 \\
\hline & 20.5 & 20.5 & 0 \\
\hline Bouillon & 15.6 & 15.1 & 3.2 \\
\hline
\end{tabular}

Table (1): Comparison between measured and calculated temperatures in wells.

\section{Conclusions}

In karst aquifers, temperature signals play an additional important role since they carry information about internal aquifer structures. A two dimension heat transport numerical model was developed to simulate the temperature distribution in a karst aquifers composed conduits and fractured systems. The model was based on the Navier Stokes equation to simulate the groundwater velocity in the conduit system where the porosity tends to one, heat transport equation to simulate the temperature distribution in a karst aquifer, and finally $\mathrm{k}-\varepsilon$ turbulent model to simulate the turbulent viscosity.

The model was applied to the karst system of the Val d'Orléans. This system is very developed in which there are many sinkhole points on the Loire river and many spring point along the Loiret river. Temperatures are measured in thirteen wells with different depth in 29 Jun 2011 when the temperature of Loire river and the Bouillon spring were $26.5^{\circ} \mathrm{C}$ and $15.6{ }^{\circ} \mathrm{C}$. Calculated results have shown that the model is not sensitive to the variation of water density, but it is sensitive to the variation of specific heat and density of the rock especially in the fractured system. Also, the model is very sensitive to any variation on the water velocity in sinkhole points, and any variation in the depth of saturated zone. The influence of the variation of the groundwater slope along the study reach is small compared 
with other parameters. The best results are occured when the water velocity in sinkhole points is $80 \mathrm{~m} / \mathrm{hr}$, the porosity is $10 \%$ in the fractured system and $80 \%$ in the conduit system and the depth of saturated zone is 25 $\mathrm{m}$. Finally, it was observed that the comparison between measured and calculated temperatures in wells is very good.

\section{References}

Albéric, P. and Lepiller, M. (1998). Oxydation de la matière organique dans un système hydrologique karstique alimenté les pertes fluviales (Loiret, France). Water Resources 32, 20512064

Albéric, P. (2008). Les trios pertesémergences (ou inversacs) du domaine de la source (Loiret). Colloque national d'Hydrogéologie. May 16 and 17, Orléans -France

Andre, B.J., Rajaram, H. (2005). Dissolution of limestone fractures by cooling waters: Early development of hypogene karst systems. Water Resources Research 41 (1), 1-16.

Andrieux, C. (1978). The experiences form the temperature in the karst (in French). Colloque de Tarbes, Le karst: son originalité physique, son importance économique. Association des Géologues du SudOuest (AGSO), Orleans, France, 48-63

Aravinth, S. (2000). Prediction of heat and mass transfer for full developed turbulent fluid flow through tubes. International Journal of Heat and Mass Transfer 43, 1399-1408.

Beek, W.J., Muttzall, M.K., van Heuven, J.W. (1999). Transport Phenomena, second edition. John Wiley \& Sons Ltd., West Sussex, England. 329 p.

Benderitter, Y., Roy, B., Tabbagh, A. (1993). Flow characterization through heat transfer evidence in a carbonate fractured medium: first approach. Water Resources Research 29 (11), 3741-3747.

Benim, A.C., Cagan, M., Gunes, D. (2004). Computation analysis of transient heat transfer in turbulent pipe flow.
International Journal of Thermal Sciences 43, 725-732.

Birk, S. (2002). Characterization of Karst Systems by Simulating Aquifer Genesis and Spring Responses: Model Development and Application to Gypsum Karst. Tübinger Geowissenschaftliche Arbeiten, vol. 60. Reihe C. Institut und Museum für Geologie und Paläontologie der Universität Tübingen, Tübingen, Germany. <http://w210.ub.unituebingen.de/dbt/volltexte/2002/558/>

Birk, S., Liedl, R., Sauter, M. (2004). Identification of localized recharge and conduit flow by combined analysis of hydraulic and physicochemical spring responses (Urenbrunnen, SW-Germany). Journal of Hydrology 286: 179-193

Chery, J.L. (1983). Etude hydro chimique d'un aquifère karstique alimenté par perte de cours d'eau (la Loire). Thèse 3e cycle, Orléans

Crowther, J., Pitty, A.F. (1982). Water temperature variability as an indicator of shallow-depth groundwater behaviour in limestone areas in west Malaysia. Ournal of Hydrology 57, 137-146

Dogwiler, T., Wicks, C.M., Jenzen, E. (2007). An assessment of the applicability of the heat pulse method toward the determination of infiltration rates in karst losing stream reaches. Journal of Cave and Karst Studies 69 (2), 237 242.

Genthon, P., Bataille, A., Fromant, A., D'Hulst, D., Bourges, F. (2005). Temperature as a marker for karstic waters hydrodynamics. Inferences from 1 year recording at la Peyrere cave (Ariege, France). Journal of Hydrology 311 (1-4), 157-171.

Gnielinski, V. (1976). New equations for heat and mass transfer in turbulent pipe and channel flow. International Chemical Engineering 16 (2), 359368. 
Guillocheau, F., Robin, C., Allemand, P., Bourquin, S., Brault, N., Dromart, G., Friedenberg, $\quad$ R., Garcia, J., Gaulier, J., Gaumet, F., Grosdoy, B., Hanot, F., Le Strat, P., Mettraux, M., Nalpas, T., Prijac, C., Rigollet, C., Serrano, O., Grandjean, G. (2000). Meso-Cenozoic geodynamic evolution of the Paris Basin: 3D stratigraphic constraints Geodin. Acta 133(4), 189246

Lastennet, R. (1994). Role of unsaturated zone in the functioning of karst aquifers: approach for the physico-chemical and isotopic study of input and output (springs) of Ventoux massif (Vaucluse) (in French). PhD Thesis, Univ. Avignon and Pays de Vaucluse, France, $239 \mathrm{pp}$

Lepiller, M. (2001). Traçages appliqués à la dynamique des aquifères karstiques. Géologue (129), 79-84

Lepiller, M. and Mondain, P.H. (1986). Les traçages artificiels en hydrogéologie karstique. Hydrogéol 1, 33-52

Liedl, R., Sauter, M. (2000). Characterization of karst groundwater processes, using models of aquifer genesis and heat transport. Grundwasser 5 (1), 9-16.

Martin, J.B., Dean, R.W. (1999). Temperature as a natural tracer of short residence times for groundwater in karst aquifers. In: Palmer AN, Palmer MV, Sasowsky ID (eds) Karst Modeling. Spec. Publ. 5, Karst Waters Institute, Leesburg, VA, 236-242

Martin, J.C. and Noyer, M.L. (2003). Caractérisation du risque d'inondation par remontée de nappe sur le Val d'Orléans. Etude hydrogéologie, BRGM

O'Driscoll, M.A., DeWalle, D.R (2006). Stream-air temperature relations to classify stream-ground water interactions in a karst setting, central Pennsylvania, USA. Journal of Hydrology 329 (1-2), 140-153.

Roy, B., Benderitter, Y. (1986). Natural thermal transfer in a superficial fissured carbonate system (in French). Bull Soc Géol France 2 (4), 661-666

Yakhot, V., Orszag, S.A., Thangam, S., Gatski, T.B. and Speziale, G.C. (1992). Developments of Turbulence Models for Shear Flows by a Double Expansion Technique, Physics of Fluids A, 4 (7), 1510-1520

Zunino, (1979). Contribution à l'étude hydrogéologique du Val d'Orléans. Ph.D. thesis, Orleans University

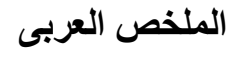

\section{نمذجة نقل الحرارة في طبقة المياه الجوفية الكارستية لمدينة اورليانز (فرنسا)}

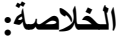

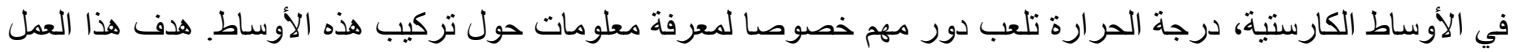

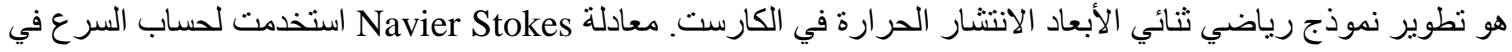

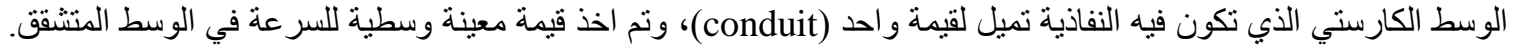

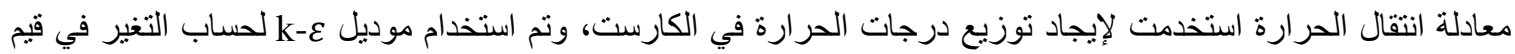

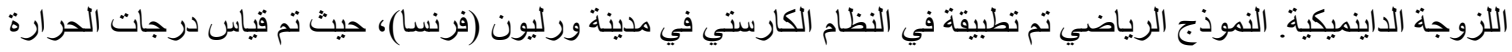

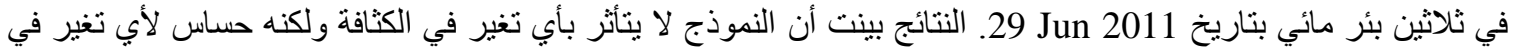

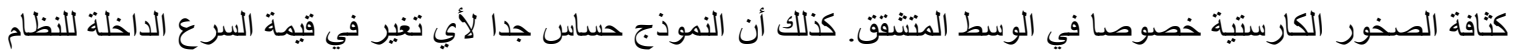

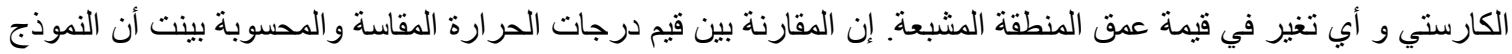

